\title{
UMA VISÃO GARANTISTA SOBRE PROVA PENAL PRODUZIDA DE OFÍCIO PELO MAGISTRADO FRENTE AO PROCESSO PENAL CONSTITUCIONAL
}

Valine Castaldelli Silva*

Alexandre Ribas de Paulo**

SUMÁRIO: Introdução; 2 O garantismo como ferramenta de interpretação de princípios do Processo Penal afetos à Constituição Federal de 1988; 3 O Código de Processo Penal de 1941 e a esperança do processo penal constitucional; 4 Os limites da produção probatória; 5 Considerações finais; Referências.

RESUMO: Os contextos históricos tão diversos nos quais o Código de Processo Penal de 1941 e a Constituição Federal de 1988 estão inseridos permitem inferir de imediato o evidente descompasso entre os principais discursos legislativos pertinentes ao ius puniendi no Brasil. O objetivo do presente trabalho é analisar as limitações constitucionais da prova penal produzida de ofício pelo julgador com fundamento na construção teórica do denominado processo penal constitucional. O método utilizado é o indutivo, a técnica de pesquisa é a revisão bibliográfica. Conclui-se 0 art. $5^{\circ}$, da Constituição em vigência, que trata dos direitos e garantias fundamentais do indivíduo, deveriam frear a atuação do magistrado em duplicar e dublar as funções do órgão acusador em busca de provas que evitem a absolvição dos acusados nas fases da persecutio criminis. Assim, a prova colhida com violação dos limites ético-jurídicos, especialmente contrários aos princípios do devido processo legal e a ampla defesa, merecem ser entendidas como obtidas por meio ilícito, e, por isso, devem ser inutilizadas no processo penal.

PALVRAS-CHAVE: Limites constitucionais; Prova penal no Brasil; Processo Penal Constitucional; Garantismo.

\footnotetext{
"Mestre em Ciências Jurídicas pelo Centro Universitário de Maringá (UniCesumar). Doutoranda no Programa de Pós-Graduação em Direito da Universidade Federal de Santa Catarina (PPGD/UFSC). Brasil.

E-mail: valine_cs@hotmail.com

*** Docente Adjunto TIDE na Universidade Estadual de Maringá (UEM). Doutor em Direito pelo Programa de PósGraduação em Direito da Universidade Federal de Santa Catarina (PPGD/UFSC), na área de Direito, Estado e Sociedade. Pós-Doutor em Direito, Política e Sociedade pelo PPGD/UFSC. Brasil.
} 


\title{
A GUARANTEED PERSPECTIVE ON PENAL PROOF OFFICIALLY PRODUCED BY THE MAGISTRATE IN THE WAKE OF CONSTITUTIONAL PENAL PROCESS
}

\begin{abstract}
The different historical contexts in which the 1941 Penal Code and the 1988 Brazilian Constitution are inserted proves the evident gap between the main law discourses belonging to the Brazilian ius puniendi. Current analysis deals with the constitutional limitations of the penal proof produced ex officio by the magistrate, based on the theoretical construction of the constitutional penal process. The inductive method and bibliographical review research technique reveals that Art. 5 of the Brazilian Constitution dealing with the individual's basic rights should rein the magistrate's agency in duplicating the function of the accusing organ in search of proof that avoids the absolution of the accused in the persecutio criminis phases. Proofs retrieved through the violation of ethic and juridical limits, particularly contrary to the principles of the legal process and of wide defense should be treated as obtained illicitly and should be eliminated from the penal process.
\end{abstract}

KEY WORDS: Constitutional limits; Penal proof in Brazil; Constitutional penal process; Guarantee.

\section{UNA MIRADA GARANTISTA SOBRE PRUEBA PENAL PRODUCIDA DE OFICIO POR EL MAGISTRADO FRENTE AL PROCESO PENAL CONSTITUCIONAL}

RESUMEN: Los contextos históricos muy diversos en los cuales el Código de Proceso Penal de 1941 la Constitución Federal de 1988 están inseridos permiten inferir de inmediato el evidente descompaso entre los principales discursos legislativos pertinentes al ius puniendi en Brasil. El objetivo del presente estudio es analizar las limitaciones constitucionales de la prueba penal producida de oficio por el juzgador con fundamento en la construcción teórica del denominado proceso penal constitucional. El método utilizado es el inductivo, la técnica de investigación es la revisión bibliográfica. Se concluye el art. $5^{\circ}$, de la Constitución en vigencia, que trata de los derechos y garantías fundamentales del individuo, deberían frenar la actuación del magistrado en duplicar y doblar las funciones del órgano acusador en búsqueda de pruebas que eviten la absolución de los acusados en las fases de la persecutio criminis. Así, la prueba recolectada con violación de los límites éticojurídicos, especialmente contrarios a los principios del debido proceso legal y la amplia defensa, merecen ser entendidas como obtenidas por medio ilícito, y, por eso, deben ser inutilizadas en el proceso penal.

PALBRAS CLAVE: Límites constitucionales; Prueba penal en Brasil; Proceso Penal Constitucional; Garantizado. 


\section{INTRODUÇÃO}

O Código de Processo Penal em vigor foi editado em 1941 sob a égide da Constituição de 1937 que foi outorgada por Getúlio Vargas na conhecida ditadura do Estado Novo. ${ }^{03}$ Durante os quase 80 anos de vigência desse Codex, outras três constituições foram promulgadas, datadas de 1946, 1967 (e emenda constitucional de 1969) e 1988.

Nota-se que o Código de Processo Penal, embora em relativo pouco espaço de tempo, transitou pelos mais diversos contextos históricos e Constituições que o país já teve e tem, sobrevivendo tanto em períodos ditatoriais quanto na denominada democracia; o que é curioso.

$\mathrm{O}$ atual cenário político e social em que o Código de Processo Penal e a Constituição Federal de 1988 estão inseridos permite perceber de imediato o evidente descompasso entre ambos. ${ }^{04}$ Ainda que o Código de Processo Penal tenha sido editado antes da Constituição Federal de 1988 e haja manifesta desarmonia entre ambos, a leitura dos dispositivos daquele deveria ser realizada sob a ótica dos direitos e das garantias individuais elencadas pela Constituição Federal em vigência, e não a partir do que Alexandre Morais da Rosa denomina de disposições equivocadas do Código de Processo Penal. ${ }^{05}$

A Constituição Federal de 1988, no rol dos Direitos e Garantias Fundamentais (direitos e deveres individuais e coletivos), especificamente nos incisos do art. $5^{\circ}$, declara as garantias processuais, muitas delas decorrentes de tratados internacionais de Direitos Humanos, que visam proteger o indivíduo e sua personalidade, tendo em vista a necessidade de se estabelecer o equilíbrio entre as partes perante o exercício da jurisdição e frear os abusos do poder público, especialmente quando este exerce sua pretensão punitiva.

No presente artigo, primeiramente será realizada uma exposição da teoria

\footnotetext{
03 "O sistema processual brasileiro é fundamentalmente o mesmo (tanto o civil quanto o penal), desde os tempos do Estado-Novo até ao presente, apesar das mutações políticas por que o país tem passado." (In: DINAMARCO, Cândido Rangel. A Instrumentalidade do Processo. São Paulo: Malheiros, 2013, p. 369).

${ }^{04}$ Nesse sentido a exposição de Geraldo Prado: "[...] convém ainda explicitar em que circunstâncias históricas, determinados valores estruturantes do processo penal constituíram objeto da atenção e da regulação constitucional, em contraposição ao fundo cultural que posteriormente veio alicerçar a maior parte das leis processuais, densificando-se interpretações doutrinárias aparentemente distintas dos caminhos apontados pela Lei Maior. A análise crítica conecta ao estudo jurídico das diversas categorias processuais o exame das condições historicamente verificadas por ocasião da edição das normas." (In: Sistema acusatório: A conformidade constitucional das leis processuais penais. Rio de Janeiro: Lumen Juris, 2005, p. 38).

${ }^{05}$ ROSA, Alexandre Morais da. Guia compacto do processo penal conforme a teoria dos jogos. Rio de Janeiro: Lumen Juris, 2014, p. 177.
} 
garantista do jurista e filósofo Luigi Ferrajoli como ferramenta de intepretação dos princípios processuais elencados na Constituição Federal. Após, será elaborada uma abordagem constitucional do Processo Penal, ou seja, como que está estruturado o ius persequendi em relação aos sujeitos processuais e Direitos e Garantias Fundamentais. Finalmente, abordar-se-ão os limites da produção probatória realizada de ofício pelo magistrado, buscando-se compreender quais seus limites e validade.

\section{O GARANTISMO COMO FERRAMENTA DE INTERPRETAÇÃO DE PRINCÍPIOS DO PROCESSO PENAL AFETOS À CONSTITUIÇÃO FEDERAL DE 1988}

A teoria garantista idealizada pelo jurista e filósofo do direito italiano Luigi Ferrajoli, na sua primeira acepção, corresponde a um modelo de sistema de estrita legalidade do Estado de Direito ${ }^{06}$. No plano epistemológico, corresponde a um sistema de poder mínimo estatal. Já no plano político, concerne a uma técnica de tutela no âmbito jurídico que visa minimizar a violência pública e maximizar a guarida da liberdade individual ${ }^{07} \mathrm{O}$ padrão normativo dos declarados direitos humanos pela cultura jurídica ocidental contemporânea segue, a princípio, essa proposta ${ }^{08}$

Arnaldo Miglino, no texto "Breves Reflexões sobre o Significado do Garantismo [em vista dos acontecimentos italianos dos anos 1988-1994]", explica que o termo garantismo surgiu para "[...] individualizar aquelas teorias, políticas antes que jurídicas, dirigidas a proteger a liberdade do cidadão de qualquer abuso ou arbítrio de quem exercita o poder." ${ }^{\text {09 }}$ Portanto, o autor entende por garantismo o conjunto de todas as regras que disciplinam os modos de interpretação da intervenção repressiva do Estado, em favor do indivíduo.

O Estado, na sua dupla e paradoxal qualidade, uma de detentor do ius puniendi e a outra de julgador imparcial dos conflitos, tem o dever ético de concretizar

${ }^{06}$ FERRAJOLI, Luigi. Derecho y razón. Tradução de Perfecto Andrés Ibáñez, Alfonso Ruiz Miguel, Juan Carlos Bayón Mohino,Juan Terradillos Basoco e Rocío Cantarero Bandrés. Madrid: Editorial Trotta, 1995, p. 851. Título Original: Diritto e ragione. Sobre a obra, Gustavo Noronha de Ávila menciona que é de inspiração contratualista em resposta aos movimentos de política criminal da segunda metade da década de 70. (In: O debate entre Luigi Ferrajoli e os abolicionistas: entre a sedução pelo discurso do medo e as práticas libertárias. Revista Jurídica Cesumar, v. 16, n. 2, p. 543-61, maio/ago 2016).

${ }^{07}$ Ibidem, p. 851-2.

${ }_{08}^{08}$ Todo sistema que se ajusta normativamente ao modelo e o satisfaz efetivamente pode ser denominado de garantista. Idem.

${ }^{09}$ MIGLINO, Arnaldo. RODRIGUES, Horácio Wanderlei (org.). Lições alternativas de direito processual. São Paulo: Editora Acadêmica, 1995, p. 44. 
os direitos e garantias fundamentais pertinentes à jurisdição como, por exemplo, os princípios do devido processo legal, contraditório e ampla defesa, vedação das provas ilícitas etc.. Deveras, no decorrer do processo penal, momento em que o Estado exerce sua pretensão punitiva, a obediência aos ditames constitucionais tenciona a diminuir o desequilíbrio entre o ius puniendi e o ius libertatis. ${ }^{10}$

Portanto, a produção probatória no Processo Penal só pode ser considerada válida se respeitados os direitos e garantias constitucionais que o próprio Estado prometeu e declarou a todas as pessoas que vivem no Brasil, entre elas: ser processado e sentenciado pela autoridade competente (art. $5^{\circ}$, inciso LIII, da Constituição Federal); devido processo legal (art. $5^{\circ}$, inciso LIV, CF); contraditório e ampla defesa (art. $5^{\circ}$, inciso LV, CF), inadmissibilidade das provas obtidas por meios ilícitos (art. $5^{\circ}$, inciso LVI, CF), dentre outras. ${ }^{11}$

As garantias acima citadas encontram-se entre orientações reconhecidas pelos textos internacionais e incorporados nacionalmente, na Constituição Federal de 1988 , como se observa nos parágrafos $2^{\circ} \mathrm{e} 3^{\circ}$, do artigo $5^{\circ}$. Vale dizer que o respeito às diretrizes internacionalmente aceitas no mundo ocidental reflete os princípios de justiça que foram sendo aperfeiçoadas nos últimos séculos, especialmente após a Revolução Francesa e, no Brasil, encontra seu principal aporte na Convenção Americana Sobre Direitos Humanos, por meio do decreto $n^{0} 678 / 92 .{ }^{12}$

A previsão das mencionadas garantias processuais penais em cláusulas constitucionais consideradas pétreas, conforme a redação do artigo $60, \S 4^{\circ}$, inciso

\footnotetext{
${ }^{10}$ Luigi Ferrajoli defende que o modelo garantista é aplicável a outras áreas do direito, como por exemplo, o constitucional e o internacional. (Op. cit., p. 854). Gustavo Noronha de ávila sustenta a necessidade de questionamento da legitimidade da legislação penal brasileira: "Possível perceber, portanto, que a noção de "[...] ilegalismo", em Foucault, põe em xeque não o ato humano que transgride a norma jurídica (v.g. a ilegalidade), mas sim essa estratégia política, usualmente operada pelo Estado, que instrumentaliza a percepção social sobre a violência, visando, com isso, a criação de uma delinquência útil, legítima em última análise, que autoriza a adoção de expedientes jurídicos extraordinários, muitas vezes contrários a própria lei." (RAMOS, Butteli Marcelo; ÁVILA, Gustavo Noronha de. A persistência do fracasso prisional: a hipótese do ilegalismo em Michel Foucault. Carta Capital, mar/2015. Disponível em: http://justificando.cartacapital.com. br/2015/03/12/a-persistencia-do-fracasso-prisional-a-hipotese-do-ilegalismo-em-michel-foucault/. Acesso em 24 de junho de 2018).

${ }^{11} \mathrm{Na}$ medida em que tais princípios estão incorporados no ordenamento positivo, na forma de princípios constitucionais ou legais, tem-se um modelo normativo de legitimidade jurídica ou validez. (FERRAJOLI, Luigi. Op. cit., p. 97). O processo judicial, acusação, defesa e prova designam condições ou garantias processuais. Dessa maneira um sistema garantista é um modelo limite, composto pelos seguintes princípios: nulla poena sine crimine, nullum crimen sine lege, nulla lex (poenalis) sine necessitate, nulla necessitas sine iniuria, nulla iniuria sine actione, nulla actio sine culpa, nulla culpa sine iudicio, nullum iudicium sine accusatione, nulla accusatio sine probatione, nulla probatio sine defensione. Esses princípios podem ser incorporados às Constituições e convertem-se em princípios do Estado de Direito. (Ibidem, p. 92-3).

12 BRASIL, Brasília. Decreto 678, de 06 de novembro de 1992. Promulga a Convenção Americana sobre Direitos Humanos (Pacto de São José da Costa Rica), de 22 de novembro de 1969. Disponível em: http://www.planalto. gov.br/ccivil_03/Decreto/D0678.htm. Acesso em: 07 de agosto de 2018.
} 
IV, assegura a superioridade desses princípios, individuais, ainda que a cultura social os entenda como proteção de criminosos ${ }^{13}$, ou que os atores do sistema político-jurídico não os coloquem em prática. ${ }^{14}$ Afinal Ferrajoli mesmo exprime sua desconfiança ao mencionar que o sistema garantista é um modelo limite, ideal, que nunca foi e nunca será realizável. ${ }^{15}$

Levando-se em consideração que a Constituição Federal de 1988 proclama as garantias processuais penais e o Estado detém do monopólio da administração da Justiça, há a necessidade de que o exercício do ius puniendi, de legitimidade do Estado-administração, ${ }^{16}$ realize-se em conformidade com as diretrizes legais de modo que haja equilíbrio na relação jurídica cogente entre Estado versus indivíduo quando se trata de ação penal pública. ${ }^{17}{ }^{18}$ Dessa maneira, incumbe ao julgador conhecer e aplicar os dispositivos constitucionais nos casos concretos, de modo a tutorar o processo de modo que as garantias processuais penais não se tornem letra morta e inacessíveis aos milhares de jurisdicionalizados, lembrando que o Poder Judiciário não faz parte da segurança pública brasileira - artigo 144 da Constituição Federal - para buscar a punição de supostos infratores penais, mas é um dos poderes da União - artigo $2^{\circ}$ da Constituição Federal - que tem a nobre missão de

${ }_{13}$ Louk Hulsman (Penas perdidas: o sistema penal em questão. Niterói: Luam, 1993, p. 55), um dos principais teóricos contemporâneos do chamado "abolicionismo penal", iniciado a partir da metade da década de 70 do século XX, salienta: "Ao tratarem dos problemas da justiça penal, os discursos políticos, grande parte da mídia e alguns estudiosos da política criminal se põem de acordo e dão a palavra a um determinado 'homem comum'. Este homem comum seria obtuso, covarde e vingativo. Não faria distinção entre marginais, os violentos, os molestadores de todos os tipos. Imaginaria as prisões cheias de perigosos assassinos. E veria no aparelho penal o único meio de proteção contra os fenômenos sociais que o perturbam."

${ }^{14}$ PRADO, Geraldo. Op. cit., p. 89-90.

${ }^{15}$ FERRAJOLI, Luigi. Op. cit., p. 38. Gustavo Noronha de Ávila tece críticas: "[...] é necessário entender que as teses defendidas pelo minimalismo garantista são simplesmente critérios a serviço da (re)legitimação do poder punitivo. [...] teorias legitimadoras do sistema penal (caso do garantismo de Ferrajoli) precisam ser repensadas de acordo com seu alcance e perspectiva de efetividade." (Op. cit.).

${ }^{16}$ Nas lições de Alexandre Ribas de Paulo: "[...] é por intermédio da chamada "ação penal" que o Estado concretiza o chamado ius puniendi - a pretensão de aplicar uma pena oficialmente declarada pelo próprio Estado - através de seus próprios agentes (Polícia, Ministério Público e Magistrados)." (In: PAULO, Alexandre Ribas de. A informalidade na resolução de conflitos penais intersubjetivos e no Processo Penal: um olhar histórico sobre os mecanismos de apropriação das pessoas pelos (Estados) soberanos. 2006. 204 folhas. História do Direito. Universidade Federal de Santa Catarina, Florianópolis, 2006, p. 160).

${ }^{17}$ PRADO, Geraldo. Op. cit., p. 27.

18 "O processualista moderno adquiriu a consciência de que, como instrumento a serviço da ordem constitucional, o processo precisa refletir as bases do regime democrático, nela proclamadas; ele é, por assim dizer, o microcosmo democrático do Estado de direito, com as conotações da liberdade, igualdade e participação (contraditório), em clima de legalidade e responsabilidade." (In: DINAMARCO, Cândido Rangel. Op. cit., p. 27). 
ser imparcial e justo. ${ }^{19}$

Nas lições de Cândido Rangel Dinamarco, o processo, sendo o reflexo do Estado - no Estado de Direito de cunho social -, deveria ser assinalado também pela legalidade e composto de meios que garantam a liberdade e igualdade. ${ }^{20}$

Somente um direito processual fundamentado nos direitos do indivíduo e que minimize a discricionariedade judicial poderá oferecer um sólido alicerce à independência dos magistrados e seu papel no controle de abusos de poder. Além do mais, apenas o direito penal, como um todo, guiado pela tutela dos direitos fundamentais pode efetivamente harmonizar garantismo, eficiência e segurança jurídica. $^{21}$

Alerta Ferrajoli que o problema do garantismo é elaborar técnicas (que correspondem aos limites, garantias ou condições de legitimidade do poder judicial) no plano teórico, torná-las vinculantes no plano normativo e assegurar sua efetividade no plano prático. ${ }^{22}$

Enfim, somente um direito processual fundamentado nos direitos do indivíduo e que minimize a discricionariedade estatal no ius persequendi poderá oferecer um sólido alicerce à independência dos magistrados e seu papel no controle de abusos de poder no conflito ius puniendi versus ius libertatis.

\section{O CÓDIGO DE PROCESSO PENAL DE 1941 E A ESPERANÇA DO PROCESSO PENAL CONSTITUCIONAL}

O direito processual penal, esfera do direito público, deveria ser guiado pelos fundamentos constitucionais, pois é na própria Constituição que se delimita

\footnotetext{
${ }^{19}$ Nesse sentido observa-se, por exemplo, o equívoco do processualista penal brasileiro Hélio Tornaghi (Curso de processo penal. São Paulo: Saraiva, 1990, v.1., p. 29) quando declara "Todo crime deve ser punido. A repressão compete ao Poder Judiciário. No Brasil, entretanto, a tarefa de investigar o fato e autoria é confiada a um ramo da Polícia, por isso mesmo chamada Polícia Judiciária." Argumenta-se que o Poder Judiciário deve exercer a jurisdição conforme as regras estabelecidas no Estado democrático de Direito, não lhe cabendo a responsabilidade da repressão ao indivíduo, que não possui qualquer outra alternativa exceto a de confiar que o magistrado irá ser justo e imparcial na análise de sua questão jurídica. Se ao Poder Judiciário competisse a repressão, como poderia ser explicado princípio ne procedat iudex ex officio no processo penal brasileiro?

${ }^{20}$ DINAMARCO, Cândido Rangel. Op. cit., p. 369.

${ }^{21}$ FERRAJOLI, Luigi. Op. cit., p. 10.

${ }^{22}$ Ibidem, p. 70.
} 
a estrutura dos órgãos jurisdicionais e estabelecem-se os princípios processuais. ${ }^{23}$ Com efeito, o direito processual penal pode ser indicado como um ramo do direito constitucional aplicado nas relações autoridade versus liberdade perante o Poder Judiciário. ${ }^{24}$

Assim, o direito processual constitucional não trata de um ramo diverso ou novel, mas cuida de uma visão metodológica e sistemática na qual se analisa o processo em suas relações com a Constituição. ${ }^{25}$

Dos 250 artigos da CF/88, praticamente todos importam na estruturação e regulação do poder estatal, restando somente um, o artigo $5^{\circ}$, que pode ser compreendido como sendo declarações de direitos que pertinem especificamente ao ser humano, e podem ser compreendidos como "não-estatais", visto que as pessoas podem opô-los contra o Estado, mas este não pode opô-los contra as pessoas.

Ao tratar da relação entre direito constitucional e direito processual penal, Fernando da Costa Tourinho Filho afirma que são "íntimas" as suas relações, visto que a Constituição "estabelece e enuncia os princípios que servem de base à jurisdição penal. Pode-se dizer até que o processo penal é a Constituição na sua dinâmica."

Com efeito, o verdadeiro Código de Processo Penal seria aquele que deveria regulamentar, precipuamente, a aplicação dos direitos e garantias individuais como limite ao ius puniendi estatal, estabelecendo as regras de produção probatória e mecanismos de tutela do acusado criminalmente, ${ }^{27}$ visto que este é sempre a pessoa vulnerável perante o poder estatal.

No Brasil, contudo, ocorre uma inversão de valores, parecendo até que, no exercício do ius persequendi et ius puniendi pelos órgãos estatais, a Constituição Federal de 1988 não teria sido totalmente "recepcionada" pelo vetusto discurso

\footnotetext{
23 "Mas além de seus pressupostos constitucionais, comuns a todos os ramos do direito, o direito processual é fundamentalmente determinado pela Constituiç̃o em muitos de seus aspectos e institutos característicos." (In: CINTRA, Antonio Carlos de Araújo; GRINOVER, Ada Pellegrini; DINAMARCO, Cândido Rangel. Teoria geral do processo. São Paulo: Malheiros, 2010, p. 84).

${ }^{24}$ Idem.

${ }^{25}$ Ibidem, p. 85.

${ }^{26}$ TOURINHO FILHO, Fernando da Costa. Processo penal. São Paulo: Saraiva, 2011, volume I, p. 52.

${ }^{27}$ Sobre o processo penal como mecanismo de legitimidade da punição estatal: "As garantias constitucionais do processo penal representam, assim, o modelo processual penal que, no plano político, nada mais é do que um espelho dos valores sociais vigentes numa determinada sociedade, em um dado período histórico. A disciplina concreta dos institutos processuais, mais do que decorrência de simples escolhas técnicas é, em verdade, fruto de uma opção politicamente orientada. A disciplina dos elementos e requisitos de um ato processual, dos sujeitos legitimados a requerê-lo, da forma com que deve ser praticado são, em verdade, escolhas de valor." (In: BADARÓ, Gustavo. A busca da verdade no processo penal e os seus limites: ainda e sempre o problema do prazo de duração de interceptação telefônica. SANTORO, Antonio Eduardo Ramires; MADURO, Flávio Mirza (org.). Interceptação telefônica: os 20 anos da Lei n 9.296/96. Belo Horizonte: Editora D’Plácido, 2016, p. 190-1)
} 
despótico do Código de Processo Penal. Deveras, este foi editado em 1941 sob a égide da Constituição de 1937, outorgada por Getúlio Vargas e que instituiu a ditadura do Estado Novo. ${ }^{28}$

Em tal contexto ditatorial, o jurista mineiro Francisco Campos foi o redator da exposição de motivos do Código de Processo Penal, que curiosamente também trabalhou na elaboração da Constituição de 1937, impregnada com um autoritarismo exacerbado, inspirada na legislação fascista italiana e na Constituição polonesa. ${ }^{29}$

A atuação de tal jurista no cenário político brasileiro se estendeu durante décadas, alcançando as reformas dos Códigos de Processo Penal e Civil, Código Penal, bem como na redação dos Atos Institucionais I e II $^{30}$ que modificaram a Constituição de $1964 .{ }^{31}$

A partir da exposição de motivos do Código de Processo Penal subscrita por Francisco Campos, pode-se desvelar o intento ideológico quanto ao direito criminal brasileiro, que residia na imposição de um ajuste "[...] ao objetivo de maior eficiência e energia da ação repressiva do Estado contra os delinquem."

Francisco Campos salientou o espírito do Código de Processo Penal no item II da exposição de motivos, denominada "A reforma do processo penal vigente":

As nossas vigentes leis de processo penal asseguram aos réus, ainda que colhidos em flagrante ou confundidos pela evidencia das provas, um tão extenso catálogo de garantias e favores, que a repressão se torna, necessariamente, defeituosa e retardatária, decorrendo daí um indireto estímulo à expansão da criminalidade. Urge que seja abolida a injustificável primazia do interesse do indivíduo sobre o da tutela social. Não se pode continuar a contemporizar com pseudodireitos individuais em prejuízo do bem comum. $\mathrm{O}$ indivíduo, principalmente quando vem de se mostrar rebelde à disciplina jurídico-penal da vida em sociedade, não pode invocar, em face do Estado, outras franquias ou

${ }^{28}$ Nesse contexto, Gustavo Noronha de Ávila expõe que a oposição entre marcos autoritários e democráticos caracterizam a história do processo penal. (In: Falsas memórias e sistema penal: a prova testemunhal em xeque. Rio de Janeiro: Lumen Juris, 2013, p. 07).

${ }^{29}$ CHAMBÔ, Pedro Luiz. O estado de exceção como regra: Um estudo histórico-constitucional do Estado Novo (1937-1945). Revista da Faculdade de Direito (USP), v. 108, p. 117-128, 2013.

30 Atos Institucionais. Disponível em: http://www4.planalto.gov.br/legislacao/portal-legis/legislacao-historica/ atos-institucionais. Acesso em 24 de junho de 2018.

31 MENEZES, Daniel Francisco Nagao; JUNQUEIRA, Michelle Assato. O Estado subsidiário na Constituição de 1937: o papel de Francisco Campos. Disponível em: http://www.publicadireito.com.br/ artigos/?cod=be3ac64e67e84198. Acesso em 24 de junho de 2018. 
imunidades além daquelas que o assegurem contra o exercício do poder público fora da medida reclamada pelo interesse social. Este o critério que presidiu à elaboração do presente projeto de Código. No seu texto, não são reproduzidas as fórmulas tradicionais de um mal-avisado favorecimento legal aos criminosos. O processo penal é aliviado dos excessos de formalismo e joeirado de certos critérios normativos com que, sob o influxo de um mal-compreendido individualismo ou de um sentimentalismo mais ou menos equívoco, se transige com a necessidade de uma rigorosa e expedita aplicação da justiça penal..$^{32}$ (sem grifos no original)

A exposição de motivos em comento dedica uma parte aos esclarecimentos relativos à produção probatória. Nela foi tratado, desde o início, sobre atribuição ao juiz quanto à sua iniciativa de produzir provas no curso da ação penal antes da prolação da sentença. ${ }^{33} \mathrm{~A}$ verdade material deveria ficar subordinada às provas constantes nos autos e, por isso, houve um alerta de que o juiz deixaria de ser um mero espectador no processo, fato esse que o inseriu como responsável pelo resultado final da causa. Nesse ponto, o Estado ditatorial da década de 40, ao contrário de regular um sistema processual acusatório - ou seja, das partes -, parece ter criado a obrigação de o magistrado buscar elementos para evitar a absolvição do acusado. ${ }^{34}$

Assim estão, sub-repticiamente, instauradas as contradições entre a ideologia inspiradora do discurso do Código de Processo Penal e o atual texto da Constituição

\footnotetext{
32 BRASIL. Códigos 3 em 1 Saraiva: Penal; Processo Penal e Constituição. São Paulo: Saraiva, 2015, p. 349-57.

33 "O projeto abandonou radicalmente o sistema chamado da certeza legal. Atribui ao juiz a faculdade de iniciativa de provas complementares ou supletivas, quer no curso da instrução criminal, quer a final, antes de proferir a sentença." (Idem).

${ }^{34}$ Item VII, das exposições de motivo: "[...] Por outro lado, o juiz deixará de ser um espectador inerte da produção de provas. Sua intervenção na atividade processual é permitida, não somente para dirigir a marcha da ação penal e julgar a final, mas também para ordenar, de ofício, as provas que lhe parecerem úteis ao esclarecimento da verdade. Para a indagação desta, não estará sujeito a preclusões. Enquanto não estiver averiguada a matéria da acusação ou da defesa, e houver uma fonte de prova ainda não explorada, o juiz não deverá pronunciar o in dubio pro reo ou o non liquet." (Idem).
} 
Federal de 1988, em que as incoerências são manifestas ${ }^{35}$. Isso, a despeito das várias inclusões, modificações e revogações que o Código sofreu a partir de $1942 .{ }^{36}$

Com o advento da Constituição Federal de 1988, as garantias relativas ao processo penal ficaram compreendidas genericamente no princípio devido processo legal (art. $5^{\circ}$, inciso LIV) ${ }^{37} \mathrm{O}$ conjunto das demais garantias constitucionais deveriam propiciar às partes o exercício equânime de suas faculdades e poderes processuais, assegurando o imparcial exercício da jurisdição estatal. ${ }^{38}$

Deveras, mais da metade dos 78 incisos do referido artigo $5^{\circ}$, da Constituição Federal, tratam de maneira direta ou indireta sobre regras a serem observadas no âmbito criminal e declaram as áreas em que autonomia do indivíduo não pode ser invadida e nem usada de modo prejudicial pelo ius persequendi estatal.

Na prática, fica instaurada a aporia entre os direitos e as garantias individuais e o Poder do Estado, visto que, como já dito, ao Judiciário foi confiada a função de mediar os conflitos existentes entre o ius libertatis e o ius puniendi e, ao mesmo tempo, contribuir com os órgãos afetos à segurança pública para o fim de produzir provas para o processo penal.

Pela lógica garantista e utilizando-se dos discursos, ao menos propedêuticos,

\footnotetext{
35 Isso pode ser notado, por exemplo, nos casos de interceptação de correspondência: "No entanto, antes da Constituição brasileira de 1988, eram excepcionais e incongruentes as previsões legislativas a respeito da proibição das provas obtidas ilicitamente. Exemplo disso sã̃o as disposições contraditórias do Código de Processo Penal de 1941 a respeito da interceptação de correspondência, que bem revelam a ideologia autoritária daquele diploma: no art. 233, é expressamente previsto que 'as cartas particulares, interceptadas ou obtidas por meios criminosos, não serão admitidas em juízo'; já o art. $240, \S 1 .^{\circ}$, letra f, autoriza a apreensão de cartas, abertas ou não, destinadas ao acusado ou em seu poder, 'quando haja suspeita de que o conhecimento do seu conteúdo possa ser útil à elucidação do fato'. Assim, o legislador fez uma distinção - que hoje parece claramente inconstitucional - entre a correspondência do acusado, que poderia ser violada, no interesse da apuração dos fatos, e as outras cartas apreendidas com violação à lei penal, inutilizáveis como prova." (In: GOMES FILHO, Antonio Magalhães Gomes. A inadmissibilidade das provas ilícitas no processo penal brasileiro. Doutrinas essenciais processo penal. Revista dos Tribunais, São Paulo, ano 1, v. III, jun. 2012).

36 Disponível em: http://www2.camara.leg.br/legin/fed/declei/1940-1949/decreto-lei-3689-3-outubro-1941322206-norma-pe.html. Acesso em: 07 de agosto de 2018. Sobre a necessidade de reforma e adequação do Código de Processo Penal à "nova" realidade constitucional, principalmente, no que tange à produção probatória: "Um dos reflexos à alteração processual, em concordância com a ideologia do Estado à época, é a presença do discurso pela descoberta da verdade a partir da normatização de investigação oficiosa ou produção probatória por parte do juiz, fundada na redução à instrumentalidade das formas e na eficácia processual. A partir da concepção tradicional de processo como relação jurídica, com a característica básica do processo jurisdicional e consequente fortalecimento do poder de valoração livre, inclusive com os elementos de prova produzidos pelo próprio julgador, cria-se uma independência ao diálogo das partes, ou seja, com a imagem de um juiz livre à busca de uma verdade, produzindo provas e afastado de regras de valoração probatória." (In: SAMPAIO, Denis. A legitimação da defesa para requerer a interceptação telefônica: um avanço ao método do contraditório no projeto de reforma do CPP. SANTORO, Antonio Eduardo Ramires; MADURO, Flávio Mirza (org.). Interceptação telefônica: os 20 anos da Lei nº 9.296/96. Belo Horizonte: D'Plácido, 2016, p. 127).

${ }^{37}$ FERNANDES, Antonio Scarance. Processo penal constitucional. São Paulo: Revista dos Tribunais, 2005, p. 45.

${ }^{38}$ CINTRA, Antonio Carlos de Araújo; GRINOVER, Ada Pellegrini; DINAMARCO, Cândido Rangel. Op. cit., p. 88.
} 
dos dogmáticos processualistas contemporâneos, tem-se que o processo penal é a Constituição em sua dinâmica e, portanto, a não observância das garantias constitucionais nas fases do ius persequendi acarreta em um processo violador dos valores humanos e democráticos. ${ }^{39}$

Nessa perspectiva, as palavras de Rui Barbosa são precisas.

De nada serviria ao povo que suas instituições baixassem do céo, ou fossem directamente, plantadas por mãos divinas, si a terra, onde caem, não fosse capaz de produzir a inteireza de animo e a coragem do dever, para as executar. O espirito do estadista constroe as garantias; mas, si não houver homens no meneio da machina, "quem garantirá as garantias? ${ }^{20}$

Portanto, de nada adiantariam as previsões constitucionais de inúmeras garantias relacionadas ao processo penal se os que deveriam observá-las as negligenciam em prol de um discurso abstrato de combate à criminalidade. Não é suficiente o mero discurso de garantias, é necessário que elas sejam efetivadas concretamente no Poder Judiciário, ${ }^{41}$ especificamente no processo penal em que há ingerência do Estado no ius libertatis do indivíduo, visto que este se se trata de um direito indisponível e o direito não permite barganhas que possam prejudicá-lo sem que haja defesa cogente. ${ }^{42}$

\footnotetext{
39 "O processo penal é, sem dúvida, o palco mais dramático da condição humana. É o momento em que o homem se vê privado de toda sua dignidade, de toda a sua intimidade, exposto aos olhos curiosos do mundo como um objeto numa vitrine." (In: AVOLIO, Luiz Francisco Torquato. Provas ilícitas. São Paulo: Revista dos Tribunais, 2015).

${ }^{40}$ BARBOSA, Ruy. A constituição e os actos inconstitucionais do congresso e do executivo ante a justiça federal. Rio de Janeiro: Atlântida Editora, 1893, p. 258.

${ }^{41}$ Sobre a necessidade de previsão de regras procedimentais as lições de Guilherme Madeira Dezem "Sabidas de antemão as regras procedimentais, sabidos são os caminhos e os rumos do processo, o que gera segurança para as partes." Acrescenta o autor, que a mera previsão de garantias na legislação não é suficiente: "[...] a proteção dos indivíduos não pode ser garantida unicamente pela legislação. Aliás, ao contrário, esta constatação serve para demonstrar que as leis, por si só, não são garantia de um processo justo. Ao mesmo tempo em que foi demonstrado que as leis por si só não são garantias de um processo justo deve ser buscado por todos aqueles que atuam processualmente." (In: A flexibilização no processo penal. 2013. Direito processual. São Paulo, Faculdade de Direito da Universidade de São Paulo).

${ }^{42}$ Geraldo Prado menciona que a maioria dos doutrinadores brasileiros: "[...] possibilitam uma promíscua convivência entre funções constitucionais e processuais penais, que me tema de direitos fundamentais pode conduzir ao arbítrio ou às suas proximidades. [...]" E acrescenta: "E preciso, pois, situar o problema. Cuidamos do regime dos direitos, liberdade e garantias. Mais: tratamos da restrição ao exercício desses direitos. Assim, é intuitivo admitir que será a metódica constitucional a base dogmática a servir de marco teórico, influenciando a aplicação de ferramenta jurídica cuja atuação nada mais é do que implementação dessas restrições." (In: Limite às interceptações telefônicas e a jurisprudência do Superior Tribunal de Justiça. Rio de Janeiro: Editora Lumen Juris, 2006, p. 20, 22).
} 


\section{OS LIMITES DA PRODUÇÃO PROBATÓRIA}

O processo penal tem como incumbência prática demonstrar se o acusado merece ou não ser apenado com a sanção preconizada na lei penal, ${ }^{43}$ ou seja, verificar se um determinado fato ${ }^{44}$ ilícito aconteceu ou não, e para tanto é necessária uma análise que se volta para o passado, na tentativa de se verificar o que de fato ocorreu dentro dos autos. Essa reconstrução da história é incumbência da prova no processo. ${ }^{45}$

A prova é o instrumento pelo qual o magistrado deve formar a sua convicção a respeito da ocorrência ou não de um determinado fato ${ }^{46} \mathrm{e}$, mesmo conforme as regras do Código de Processo Penal (art. 155), deve ser produzida em consonância com o contraditório judicial, com exceção da prova antecipada, irrepetível ou cautelar. ${ }^{47}$ Os elementos informativos colhidos na fase investigatória não podem ser inseridos na categoria de prova, salvo de estiverem dentro da exceção expressamente mencionada ${ }^{48}$

A prova processual pode ser vista por dois ângulos. No primeiro, ela pode ser definida como um meio de representação do fato objeto do processo; no segundo, representa um meio de afirmação ou confirmação de uma hipótese. Em qualquer das alternativas, a prova deve ser uma demonstração objetiva do fato específico apurado no processo. ${ }^{49}$

O termo prova pode ser aplicado em mais de uma acepção, obtêm-se assim as seguintes distinções: "[...] fonte de prova (os fatos percebidos pelo juiz), meio de prova (instrumentos pelos quais os mesmos se fixam em juízo) e objeto de prova

43 Saliente-se que: "Nem a persecução penal, nem a punição do culpado, são valores absolutos do processo penal que não possam ceder ante um limite legal e de respeito da dignidade da pessoa humana." (In: BADARÓ, Gustavo. Op. cit., p. 198).

${ }^{44}$ Sobre a definição do termo fato: "Um fato é um pedaço de história; e a história é o caminho que percorrem, desde o nascimento até a morte, os homens e a humanidade. Um pedaço de caminho, pois. Mas de um caminho que se fez, não de caminho que se pode fazer." (In: CARNELUTTI, Francesco. As misérias do processo penal. Tradução: Eduardo Trevelin Millan. São Paulo: Editora Pillares, 2009, posição 468. Título original: Le miserie del processo penal).

${ }^{45}$ Idem.

${ }^{46}$ GRINOVER, Ada Pellegrini; FERNANDES, Antonio Scarance; GOMES FILHO, Antonio Magalhães. As nulidades no processo penal. São Paulo: Revista dos Tribunais, 2001, p. 120.

${ }^{47}$ Art. 155 . O juiz formará sua convicção pela livre apreciação da prova produzida em contraditório judicial, não podendo fundamentar sua decisão exclusivamente nos elementos informativos colhidos na investigação, ressalvadas as provas cautelares, não repetíveis e antecipadas. Código de Processo Penal.

${ }^{48}$ Nesse sentido consultar: FERNANDES, Antônio Scarance; ALMEIDA, José Raul Gavião de; MORAES, Maurício Zanoide de (Coord.). Provas no processo penal: estudo comparado. São Paulo: Saraiva, 2011, p. 14.

${ }^{49}$ Nas lições de Araken de Assis e Carlos Alberto Mollinara In: STRECK, Lênio L. et al. (org). Comentários à Constituição do Brasil. São Paulo: Saraiva/Almedina, 2013, p. 940. 
(o fato a ser provado, que deduzida a fonte se introduz no processo pelo meio de prova). "50

Pode-se, ainda, falar em prova direta ou indireta. A primeira diz respeito ao fato a ser provado, e o segundo refere-se a um fato diverso (indício) que possui relação com o fato a ser provado.$^{51} \mathrm{~A}$ tipicidade das formas, representado pelo cumprimento de determinadas preceitos legais para a colheita da prova, é uma garantia das partes, sendo essencial para a prestação jurisdicional. ${ }^{52}$ Com efeito, as provas podem ser obtidas, generalizando-se, por meio dos seguintes meios: exames, oitivas, vistorias, revistas; buscas, apreensões, sequestros; interceptações, escutas, quebras de sigilo; ações especiais para investigação de criminalidade organizada etc. ${ }^{53}$

Como já salientado, as garantias constitucionais qualificam o direito processual como instrumento para a concretização dos direitos fundamentais atribuídos no processo às partes. Em consequência, a formação da culpa do investigado/acusado é atribuição da acusação que, diga-se de passagem, geralmente dispõe de todo o aparato estatal para tanto, enquanto o polo passivo do processo penal (acusado) tem, basicamente, como único expediente o conhecimento técnico do defensor, o que se revela uma situação de clara vulnerabilidade perante o Poder Judiciário. ${ }^{54}$

Deveras, o Ministério Público, encarregado oficial para promover a ação penal pública, tem sua principiologia elencada no art. 127, caput, da Constituição Federal, e é declarado como sendo "essencial à função jurisdicional do Estado", encarregado da "defesa da ordem jurídica, do regime democrático e dos interesses sociais e individuais indisponíveis". Por outro lado, a atividade do advogado é descrita no art. 133 da Constituição Federal ${ }^{55}$ e, diferente do órgão acusador estatal,

${ }^{50}$ GRINOVER, Ada Pellegrini; FERNANDES, Antonio Scarance; GOMES FILHO, Antonio Magalhães. Op. cit., p. 121.

51 Idem.

52 Sobre o tema: "A investigação criminal e a luta contra a criminalidade devem ser conduzidas de acordo com um rito probatório legalmente predeterminado. A dignidade e a moralidade do instrumento utilizado constituem, de per si, valores e se colocam, consequentemente, como limites à atividade estatal." Ibidem, p. 25. "[...] o processo só pode fazer-se dentro de uma escrupulosa regra moral, que rege a atividade do juiz e das partes." (In: GRINOVER, Ada Pellegrini; FERNANDES, Antonio Scarance; GOMES FILHO, Antonio Magalhães. Op. cit., p. 130).

53 FERNANDES, Antônio Scarance; ALMEIDA, José Raul Gavião de; MORAES, Maurício Zanoide de (Coord.). Op. cit., p. 24.

54 "A acusação normalmente está afeta a órgão oficial. Tem este todo o aparelhamento estatal montado para ampará-lo. O acusado tem de contar somente com as suas próprias forças e o auxílio de seu advogado." (In: FERNANDES, Antonio Scarance. Op. cit., p. 53).

55 "Art. 133. O advogado é indispensável à administração da justiça, sendo inviolável por seus atos e manifestações no exercício da profissão, nos limites da lei." 
é tido como "indispensável à administração da justiça".

Com isso se observa que, embora a Constituição de 1988 tenha elencado uma série de mandamentos descritos no art. $5^{\circ}$ que guardam relação com as fases do ius persequendi, quando se definem os sujeitos processuais da lide penal, claramente coloca o órgão acusador como "essencial à função jurisdicional" enquanto que a defesa deve se contentar com a habilidade do defensor como sujeito afeto apenas à "administração da justiça".

Quanto à defensoria pública, prevista no artigo 134, da Constituição Federal, é interessante notar que o discurso jurídico a elencou como "essencial à função jurisdicional do Estado", exatamente com fez com o Ministério Público. Porém, sempre é necessário observar que o próprio artigo em comento limita a atuação da defensoria pública "aos necessitados, na forma do inciso LXXIV, do art. 50", da Constituição Federal."

Verificado que a própria Constituição Federal distingue os sujeitos processuais perante o ius persequendi em juízo, insta salientar que Alexandre Morais da Rosa aborda o processo penal como um jogo, o qual se estrutura em dois jogadores: a acusação (e seu assistente) e a defesa; e ressalta que as partes não podem ser confundidas com o julgador, cuja função, segundo o autor, é coordenar e decidir o jogo, garantindo o cumprimento das regras. ${ }^{56}$

Pelo perfil traçado pelo Código de Processo Penal de 1941, que instiga a iniciativa probatória do juiz para evitar absolvições precipitadas por eventual descuido por parte do órgão acusador em sua reponsabilidade de produzir as provas para formação da culpa e, também calcado no discurso da própria Constituição Federal que coloca o órgão acusador oficial das ações penais públicas como "essencial à função jurisdicional", fica mais que evidente a disparidade de condições da defesa no "jogo processual".

É por isso que, para que o marco teórico garantista tenha efeito prático na persecutio criminis brasileira, a leitura dos dispositivos do Código de Processo Penal deve ser realizada sob a ótica das garantias individuais elencadas na Constituição Federal, lembrando que a atenção à tipicidade das formas corresponde ao devido processo legal e, sobretudo, a cláusula pétrea do artigo $5^{\circ}$, inciso LV, da Constituição,

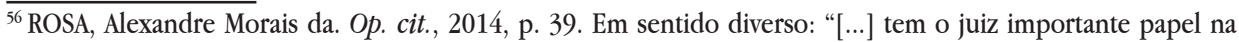
produção da prova. Para que possa proferir decisão justa e conforme a realidade, deve instruir a causa mediante efetiva participação na realização do material probatório, seja no garantir às partes a plenitude do direito à prova, seja no determinar, de ofício, a efetivação de prova relevante." (In: FERNANDES, Antonio Scarance. Op. cit., p. 77).
} 
garante a "ampla defesa" e não a ampla acusação.

Nessa perspectiva, considerando a prerrogativa do magistrado de produzir provas de ofício, este deveria utilizar tal discricionariedade para efetivar o direito do acusado a ter prova idônea sobre sua versão dos fatos, como forma de possibilitar a ampla defesa perante a acusação, de modo a diminuir as vulnerabilidades que os acusados se encontram ao responderem o tortuoso processo penal.

O magistrado, ao utilizar de sua iniciativa probatória para reforçar o papel que cabe ao órgão acusador para evitar a absolvição do acusado, assume uma atitude de "jogador" no processo e não a de julgador, ganhando ares de inquisitório um processo no qual a doutrina processual penal brasileira se esforça em salientar que é um sistema processual acusatório.

Fica clara, pois, a inversão dos valores constitucionais pertinentes aos direitos e garantias individuais, porquanto não resta qualquer alternativa ao acusado em processo criminal senão confiar na isonomia e na imparcialidade do julgador, mesmo que este seja o sujeito processual que tenha a prerrogativa de deflagrar uma intensa atividade investigativa excetuando, a seu talante, as garantias constitucionais pertinentes ao indivíduo.

A produção probatória, além das dificuldades inerentes à reconstrução de um fato passado, é passível de falhas. No processo, quando se erra o caminho trilhado na produção das provas os danos podem ser graves, ${ }^{57}$ mesmo porque o processo por si só já provoca sofrimento ao imputado, ainda que não considerado culpado ab initio. ${ }^{58}$

\section{CONSIDERAÇÕES FINAIS}

O Código de Processo Penal foi editado em 1941, sob o abrigo da Constituição de 1937, outorgada por Getúlio Vargas, fator que por si só ostenta um discurso estatal autoritário voltado ao controle total do indivíduo.

Como a Constituição Federal de 1988 possui um rol de direitos e garantias fundamentais voltados à proteção do indivíduo, para se compreender os dispositivos

\footnotetext{
${ }^{57}$ CARNELUTTI, Francesco. Op. cit.

${ }^{58} \mathrm{Na}$ continuidade do raciocínio o autor menciona que apesar de a prática da tortura ser proibida, "o próprio processo é uma tortura. [...] Ao homem, quando sobre ele recai a suspeita de ter cometido um delito, é dado ad bestias como se dizia em um tempo dos condenados oferecidos como comida para as feras." (Idem).
} 
do Código de Processo Penal na jurisdição do século XXI, no Brasil, se faz necessária a utilização de uma ferramenta de interpretação que maximize os princípios constitucionais e, por isso, foi proposto o garantismo desenvolvido pelo autor Luigi Ferrajoli.

O garantismo como ferramenta metodológica de interpretação, no plano jurídico, permite visualizar um sistema capaz de minimizar a violência estatal e maximizar a liberdade individual; contudo, trata-se de um modelo ideal. Portanto, o Estado, na qualidade de detentor exclusivo da jurisdição penal, tem o dever de observar os direitos e as garantias fundamentais em juízo, pois, no processo penal, a obediência aos ditames constitucionais tenciona diminuir o desequilíbrio entre o ius puniendi e o ius libertatis.

Como foi observado, a função do processo penal é, em síntese, declarar se o réu cometeu ou não um ato ilícito e se merece ser apenado ou não. Para isso, torna-se imprescindível a reconstrução de um determinado fato. E isso só é possível mediante a produção probatória.

A aporia que nasce entre o vetusto Código de Processo Penal e a Constituição Federal de 1988 vai além da extemporaneidade da entrada de vigência de ambos, pois encontra percalços na interpretação desde a delimitação da estrutura dos sujeitos processuais que atuarão nas fases procedimentais.

Deveras, o órgão oficial da acusação em ação penal pública no Brasil, o Ministério Público, conforme o discurso registrado no caput do artigo 127, da Constituição Federal, passou a ser "essencial à função jurisdicional do Estado". Ora, se a "função jurisdicional" pertence ao Estado-Juiz, que obrigatoriamente deve ser imparcial na apreciação de uma causa jurídica, parece que houve a duplicação da função exclusiva do Poder Judiciário por parte do órgão acusador oficial, o que não foi observado em relação à defesa dos indivíduos.

Se a Constituição Federal de 1988 salientou a essencialidade do Ministério Público para a função jurisdicional, aproximando acusador do julgador no exercício do ius puniendi, o Código de Processo Penal de 1941 já havia aproximado o julgador do acusador, pois ao juiz é facultada a produção probatória de ofício, justamente para evitar - conforme a exposição de motivos - a precipitada absolvição dos acusados.

Dessa forma, fica bastante evidenciado o prejuízo à defesa do indivíduo na lide penal, pois não só a hipersuficiência do Estado-Administração (Polícia e Ministério Público) militam na busca de provas para a condenação, mas também 
o Estado-Juiz que deveria ser imparcial, torna-se parte interessada em evitar o "benefício" da absolvição àqueles que respondem ao processo penal.

Como foi visto, a produção probatória consiste no direito subjetivo à prova, o qual se encontra abarcado pela garantia do devido processo legal conforme artigo $5^{\circ}$, inciso LIV, da Constituição Federal e que, ao contrário dos artigos que estruturam o Poder Judiciário, Ministério Público e Advocacia, trata-se de cláusula pétrea e de aplicação imediata.

Isto posto, a leitura dos dispositivos do Código de Processo Penal deve ser realizada sob a ótica das garantias individuais elencadas pela Constituição conforme os princípios insculpidos no art. $5^{\circ} \mathrm{e}$, especificamente quanto à produção probatória, a iniciativa do juiz só encontra respaldo se estiver condicente ao inciso LV, que corresponde à ampla defesa e jamais em prol do discurso ditatorial da exposição de motivos do Código de Processo Penal.

Vale lembrar também que a Constituição Federal de 1988 elegeu como garantia fundamental a inadmissibilidade das provas obtidas por meios ilícitos (art. $5^{\circ}$, inciso LVI), ou seja, aquelas produzidas em violação a princípios e normas constitucionais e disposições de direito material. A garantia constitucional é reiterada no art. 157 do Código de Processo Penal, cuja redação foi dada pela lei n. ${ }^{\circ} 11.690$ de 2008.

Por conseguinte, em uma abordagem garantista, o juiz não pode ser um duplicador e dublador das funções do Ministério Público na persecutio criminis, com uma função autoritária de produzir provas para evitar a absolvição do acusado, devendo ser entendido que as provas determinadas de ofício e que não atendam ao critério da ampla defesa do indivíduo, e em seu benefício para provar a inocência, devem ser compreendidas como obtidas por meios ilícitos e, portanto, retiradas dos autos.

\section{REFERÊNCIAS}

ÁVILA, Gustavo Noronha de. O debate entre Luigi Ferrajoli e os abolicionistas: entre a sedução pelo discurso do medo e as práticas libertárias. Revista Jurídica Cesumar, v. 16, n. 2, p. 543-561, maio/ago 2016. 
ÁVILA, Gustavo Noronha de. Falsas memórias e sistema penal: a prova testemunhal em xeque. Rio de Janeiro: Lumen Juris, 2013.

AVOLIO, Luiz Francisco Torquato. Provas ilícitas. São Paulo: Revista dos Tribunais, 2015.

BADARÓ, Gustavo. A busca da verdade no processo penal e os seus limites: ainda e sempre o problema do prazo de duração de interceptação telefônica. In: SANTORO, Antonio Eduardo Ramires; MADURO, Flávio Mirza (org.). Interceptação telefônica: os 20 anos da Lei no 9.296/96. Belo Horizonte: Editora D’Plácido, 2016.

BARBOSA, Ruy. A constituição e os actos inconstitucionais do congresso e do executivo ante a justiça federal. Rio de Janeiro: Atlântida, 1893.

BRASIL. Atos Institucionais. Disponível em: http://www4.planalto.gov.br/legislacao/ portal-legis/legislacao-historica/atos-institucionais. Acesso em 24 jun. 2018.

BRASIL. Códigos 3 em 1 Saraiva: Penal; Processo Penal e Constituição. São Paulo: Saraiva, 2015.

BRASIL. Constituição da República Federativa do Brasil de 1988. Disponível em: http://www.planalto.gov.br/ccivil_03/constituicao/constituicaocompilado.htm. Acesso em: 07 ago. 2018.

BRASIL. Decreto 678, de 06 de novembro de 1992. Promulga a Convenção Americana sobre Direitos Humanos (Pacto de São José da Costa Rica), de 22 de novembro de 1969. Disponível em: http://www.planalto.gov.br/ccivil_03/Decreto/ D0678.htm. Acesso em: 07 de agosto de 2018.

BRASIL. Decreto-lei no 3.689, de 09 de outubro de 1941. Código de Processo Penal. Disponível em: http://www.planalto.gov.br/ccivil_03/decreto-lei/ Del3689Compilado.htm. Acesso em: 07 ago. 2018.

CARNELUTTI, Francesco. As misérias do processo penal. Tradução de Eduardo Trevelin Millan. São Paulo: Pillares, 2009, posição 468. Título original: Le miserie del processo penal.

CHAMBÔ, Pedro Luiz. O estado de exceção como regra: um estudo históricoconstitucional do Estado Novo (1937-1945). Revista da Faculdade de Direito 
(USP), v. 108, p. 117-128, 2013.

CINTRA, Antonio Carlos de Araújo; GRINOVER, Ada Pellegrini; DINAMARCO, Cândido Rangel. Teoria geral do processo. São Paulo: Malheiros, 2010.

DEZEM, Guilherme Madeira. A flexibilização no processo penal: Direito processual. São Paulo: Faculdade de Direito da Universidade de São Paulo, 2013.

DINAMARCO, Cândido Rangel. A Instrumentalidade do Processo. São Paulo: Malheiros, 2013.

FERNANDES, Antônio Scarance. Processo penal constitucional. São Paulo: Revista dos Tribunais, 2005.

FERNANDES, Antônio Scarance; ALMEIDA, José Raul Gavião de; MORAES, Maurício Zanoide de (coord.). Provas no processo penal: estudo comparado. São Paulo: Saraiva, 2011.

FERRAJOLI, Luigi. Derecho y razón. Tradução de Perfecto Andrés Ibáñez, Alfonso Ruiz Miguel, Juan Carlos Bayón Mohino,Juan Terradillos Basoco e Rocío Cantarero Bandrés. Madrid: Editorial Trotta, 1995, p. 851. Título Original: Diritto e ragione.

GOMES FILHO, Antonio Magalhães Gomes. A inadmissibilidade das provas ilícitas no processo penal brasileiro. Doutrinas essenciais processo penal - Revista dos Tribunais, São Paulo, ano 1, v. III, jun. 2012.

GRINOVER, Ada Pellegrini; FERNANDES, Antonio Scarance; GOMES FILHO, Antonio Magalhães. As nulidades no processo penal. São Paulo: Revista dos Tribunais, [s.n.].

HULSMAN, Louk. Penas perdidas: o sistema penal em questão. Niterói: Luam, 1993.

MENEZES, Daniel Francisco Nagao; JUNQUEIRA, Michelle Assato. O Estado subsidiário na Constituição de 1937: o papel de Francisco Campos. Disponível em: http://www.publicadireito.com.br/artigos/?cod=be3ac64e67e84198. Acesso em 24 jun. 2018. 
direito processual. São Paulo: Editora Acadêmica, 1995.

PAULO, Alexandre Ribas de. A informalidade na resolução de conflitos penais intersubjetivos e no Processo Penal: um olhar histórico sobre os mecanismos de apropriação das pessoas pelos (Estados) soberanos. 2006. 204 f. Dissertação (mestrado) - Universidade Federal de Santa Catarina, 2006.

PRADO, Geraldo. Sistema acusatório: A conformidade constitucional das leis processuais penais. Rio de Janeiro: Lumen Juris, 2005.

RAMOS, Butteli Marcelo; ÁVILA, Gustavo Noronha de. A persistência do fracasso prisional: a hipótese do ilegalismo em Michel Foucault. Carta Capital, mar/2015. Disponível em: http:/justificando.cartacapital.com.br/2015/03/12/a-persistencia-dofracasso-prisional-a-hipotese-do-ilegalismo-em-michel-foucault/. Acesso em: 24 jun. 2018.

ROSA, Alexandre Morais da. Guia compacto do processo penal conforme a teoria dos jogos. Rio de Janeiro: Lumen Juris, 2014.

SAMPAIO, Denis. A legitimação da defesa para requerer a interceptação telefônica: um avanço ao método do contraditório no projeto de reforma do CPP. In: SANTORO, Antonio Eduardo Ramires; MADURO, Flávio Mirza (org.). Interceptação telefônica: os 20 anos da Lei no 9.296/96. Belo Horizonte: D’Plácido, 2016.

STRECK, Lênio L. et al. (org.). Comentários à Constituição do Brasil. São Paulo: Saraiva, 2013.

TORNAGHI, Hélio. Curso de processo penal. São Paulo: Saraiva, 1990.

TOURINHO FILHO, Fernando da Costa. Processo penal. São Paulo: Saraiva, 2011. Vol. I. 